Alma Mater Studiorum - Università di Bologna DEPARTMENT OF ECONOMICS

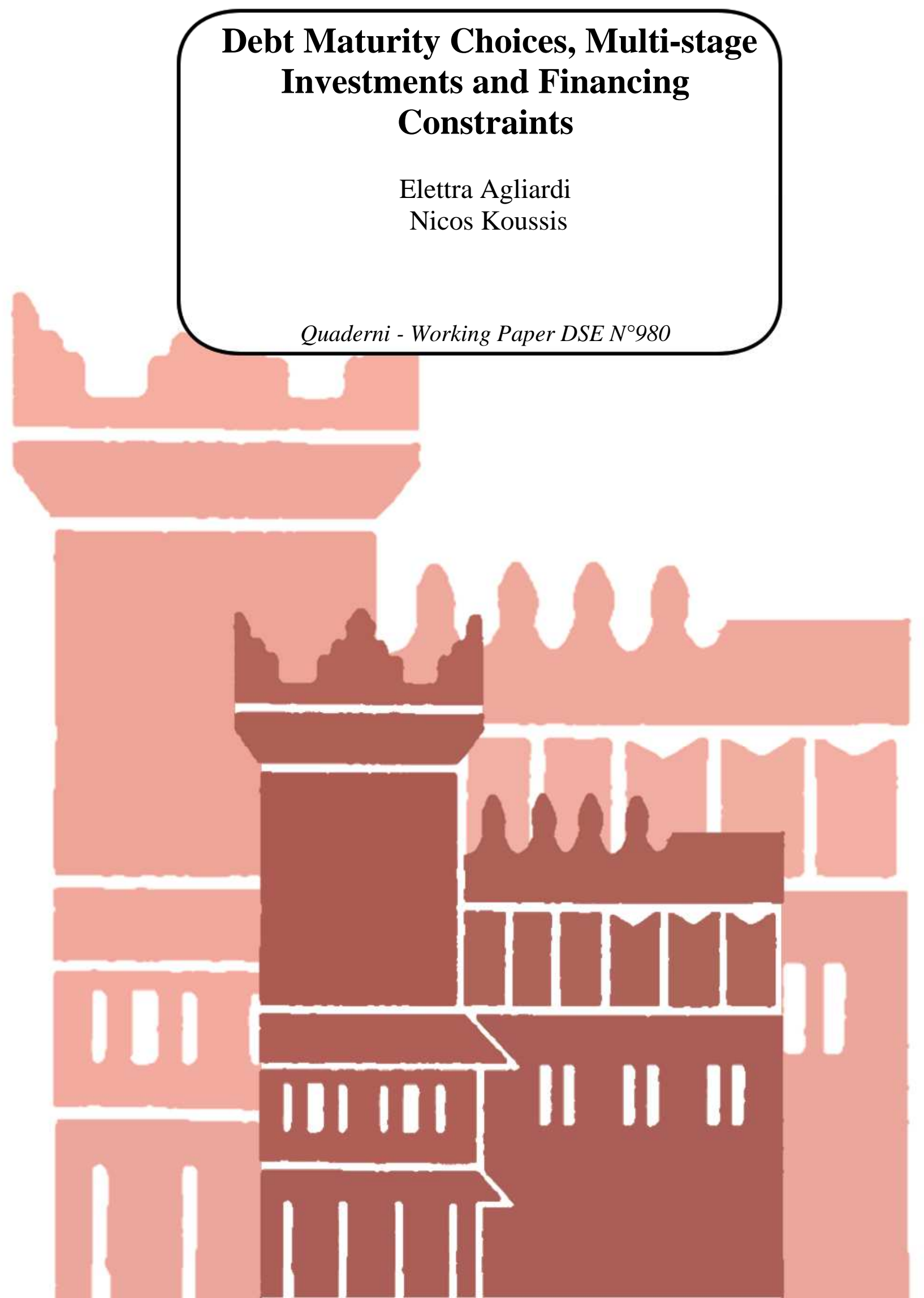




\title{
Debt Maturity Choices, Multi-stage Investments and Financing Constraints
}

\author{
Elettra Agliardi \\ Department of Economics, University of Bologna \\ elettra.agliardi@unibo.it \\ and
}

Nicos Koussis

Frederick University Cyprus

bus.kn@fit.ac.cy

Key words: optimal capital structure; financing constraints; binomial lattice models; real options.

JEL Classification: G3;G32;G33; G1 


\begin{abstract}
.
We develop a dynamic investment options framework with optimal capital structure and analyze the effect of debt maturity. We find that in the absence of financing constraints short-term debt maximizes firm value. In contrast with most literature results, in the absence of constraints, higher volatility may increase initial debt for firms with low initial revenues, issuing long term debt that expires after the investment option maturity. This effect, which is due to the option value of receiving the value of assets and remaining tax savings, does not hold for short term debt and firms with high profitability, where an increase in volatility reduces the firm value. The importance of short-term debt is reduced in the presence of non-negative equity net worth or debt financing constraints and firms behave more conservatively in the use of initial debt. With non-negative equity net worth, higher volatility has adverse effects on the firm value, while with debt financing constraints higher volatility may enhance firm value for firms with relatively low revenue that have out-of-the-money investment options.
\end{abstract}




\section{Introduction}

Understanding firms’ dynamic investment and financing decisions is a central issue of corporate finance. Recent theoretical developments in corporate finance have provided a unified framework for the analysis of investment and financing decisions of the firm. A recent example is Sundaresan and Wang (2007) who develop a two-stage investment valuation with two sequential debt issues. They provide insights on the interaction between investment and financing decisions, discussing debt overhang and leverage choices of firms in the presence of growth options. Hackbarth and Mauer (2012) use a similar dynamic model to analyze the joint choice of debt priority and capital structure with an expansion option. These papers build on trade-off theory extending Leland (1994) and are developed in a continuous time framework. ${ }^{1}$ In this paper we develop a comprehensive model along the lines of this literature. Our first contribution is to develop a computational lattice-based methodology that extends Broadie and Kaya (2007) by allowing for optimal capital structure, multiple debt issues with finite maturities and different priority rules, and multiple investment option stages. Our further contribution is that our model allows the analysis of the effect of debt maturity in the presence of multiple investment stages. While in the absence of debt or equity constraints short-term debt is preferred, we show that financing constraints may have a significant impact on firms using short-term debt, thus explaining the possible choice of long-term debt by many firms.

In the absence of financing constraints we find that firms optimally borrow more heavily when debt maturity is short and firm values are higher than in the long term debt

\footnotetext{
${ }^{1}$ Earlier examples also include Mauer and Sarkar (2005) who consider a single investment option.
} 
case, because short term debt enables firms to accelerate the receipt of tax benefits of debt. This is line with Agliardi and Koussis (2013) who find that short-term debt is optimal when there is no principal (like in the case of bank loans) and long-term debt is optimal in the case of bonds (where principal is due) similarly to Leland and Toft (1996) who also find a similar result in the absence of agency problems. Myers (1977) has first suggested that firms with growth options may optimally use short term debt that expires before the exercise of investment opportunities. Our results are consistent with empirical evidence by Altman, Gande and Saunders (2010) and Rauh and Sufi (2008) who find that firms use short term bank loans more than longer term bonds and McKay (2003) who finds higher leverage ratios for firms using shorter term debt.

Our investigation of the determinants of long-term debt in the absence of financing constraints reveals that with long term debt an increase in volatility may result in an increase in initial debt values. This result, although appearing counterintuitive, is in line with Bhagat et. al. (2009) who find that leverage is increasing with earnings risk when firms employ long-term debt. ${ }^{2}$ We show that this holds since an increase in volatility yields an enhanced option value to obtain not only the value of unlevered assets, but also the remaining tax benefits of debt since debt expires after the investment option is exercised. In contrast, for short-term debt that expires prior to the investment option exercise, an increase in volatility results in a decrease in initial debt levels.

We also investigate the effect of competitive erosion, which results in a reduction in initial and subsequent debt levels, while an increase in the expansion factor of growth

\footnotetext{
${ }^{2}$ Fan et al. (2012) show that in most countries there is a positive association between market-to-book and long term debt use (in the US the relationship is negative as also shown in Barclay and Smith, 1995 in an earlier study). Often, high market-to-book (growth) firms are associated with higher volatility, however, there several other factors that may drive market-to-book. An explicit treatment of volatility may be more effectively test the impact on the maturity structure of debt.
} 
options or a reduction in investment costs results in enhanced debt values. These results hold for both long term and short term debt. However, we observe that leverage ratios have a U-shape in the long term debt case, but are decreasing in the short term debt case with respect to the expansion factor and the investment costs. The U-shape relationship of growth options (expansion factors and investment) with leverage was also recently demonstrated in Hackbarth and Mauer (2012). In contrast, we find that in the case of short term debt, leverage ratios are strictly decreasing in the level of the expansion factor and the investment costs.

We investigate whether the presence of financing constraints may reduce the preference for short-term debt. Our focus on financing constraints is based on the observation that optimal coupon choices in the case of short-term debt often exceed firm revenue levels at the time of debt initiation. It is thus possible that the risk of negative equity net worth or the reluctance of debt holders to provide financing unless coupon levels are below revenue levels at debt initiation may explain the choice of long term debt. Our argument is supported by alternative theoretical models provided by Childs et al. (2005) and Ju and Yang (2006) who show the problems of liquidity risk, refinancing risk and transaction costs for short-term debt. Our focus on financing constraints is also reinforced by the extensive empirical literature documenting the existence of financing constraints (see for example, Campello, Graham and Harvey, 2010, Rauh, 2006, Whited and Wu, 2006, Hubbard et al., 1995 and Whited, 1992). Limited debt capacity and other forms of financing constraints have also been incorporated in recent tests of capital structure theories (see Lemmon and Zender, 2010). Gomes et al. (2006) show that debt 
constraints represent a risk factor of firm returns ${ }^{3}$. In our model debt constraints are modeled by imposing a ceiling on the level of debt installment based on the revenue levels at the times of the decision to lend. Effectively, this imposes a constraint on the level of debt which is connected to the financial conditions of the firm at the time of debt issue. By adding realistic debt financing constraints levels on short-term levels of coupon we find a significant negative impact on firm values which may indeed justify the use of long term debt. Yang (2011) models debt constraints by imposing a cost which equity holders have to pay when issuing debt, which captures the monitoring and enforcement cost of repayment risky debt. Furthermore, in contrast to Yang (2011), where debt is repaid in the next period following the issue, in our model debt maturity is flexible and we allow for multiple debt issues.

Besides debt financing constraints, firms may also face equity financing constraints. ${ }^{4}$ Uhrig-Homburg (2005) explores costly equity issue that can lead to a cash flow shortage restriction. Hubbard and Kashyap (1992) explain that low net worth may induce or exasperate debt financing constraints. Kiyotaki and Moore (1997) show how the variation in net worth creates firm financing constraints in a model of the overall economy with business cycles. A common empirical result of these and related work is an inverse relationship between the premium (cost) of external financing and the firm's net worth (Schiantarelli, 1996). In contrast to these models, we employ a structural model to capture net worth constraints. The structural approach allows us to explicitly consider

\footnotetext{
${ }^{3}$ Hirth and Uhrig-Homburg (2010) and Koussis and Martzoukos (2011) analyze the impact of exogenous debt constraints on the timing of investment, showing a U-shape pattern of the investment threshold and leverage levels (empirical support for a U-shaped relation between internal funds and investment for financially constrained firms is detailed in Cleary at al., 2007). Titman et al. (2004) investigate the impact of financing constraints on default spreads and Lensik and Sterken (2002) discuss conditions under which credit rationing by banks may apply in a real option model

${ }^{4}$ Liquidity constraints may also affect the firm's investment decisions (see, for example, Morellec, 2001, Boyle and Guthrie, 2003, Whited, 1992, Cleary et al., 2007 and Hugonnier, Malamud and Morellec, 2012). We do not explore issues of liquidity in this paper.
} 
the investment option and the role of volatility and default risk. Equity constraints are modeled by imposing a non-negative equity net worth constraint which captures the difficulties in raising external financing in bad times in line with the above literature. Our equity net-worth constraint is different from the equity financing constraint of Yang (2011). In his model, equity constraints impose a non-negative dividend restriction, which implies that no new equity can be issued at any time. In contrast, in our model equity financing is possible; however, when equity worth becomes negative we assume it is no longer possible for the firm to obtain new financing, and thus the firm defaults.

With non-negative equity net worth constraints the firm's choice of short-term debt is reduced in order to mitigate the possibility of future negative net worth as revenue uncertainty unfolds. However, non-negative equity net worth constraints alone are insufficient to reduce firm values enough to justify the use of long-term debt. In contrast, for plausible levels of debt constraints, and confirming the empirical evidence of Yang (2011), we find that debt constraints are more significantly affecting firm values, thus providing a more plausible explanation firms using long term debt. Finally, we report two interesting results with respect to the effect of revenue volatility in the presence of financing constraints. In the presence of non-negative equity net worth constraints, an increase in volatility hurts firm value by decreasing both the value of unlevered assets and the tax benefits of debt. However, with debt financing constraints higher volatility may enhance firm value for low revenue (out-of-the money options) by increasing the option value component of firm value. For firms with high revenue (in-the-money options), an increase in volatility has little impact on firm values in the presence of debt financing constraints. 
The rest of our paper is organized as follows. Section 2 describes the model, Section 3 presents the numerical results and Section 4 concludes.

\section{The model}

We assume that revenue $P$ at $t$ is a variable that follows a geometric Brownian motion of the form:

$$
\frac{d P_{t}}{P_{t}}=a d t+\sigma d Z_{t}
$$

where $\alpha, \sigma>0$ are constant parameters and $d Z_{t}$ is the increment of a standard Wiener process. The firm pays an operational cost $C$ so that total earnings before interest and taxes at time $t$ is $P_{t}-C$. The firm decides whether to exercise its investment option at time $T_{1}$ by paying an irreversible fixed cost $I_{1}$ and choosing a mix of debt $D_{1}(P)$ and equity ( $\left.I_{1}-D_{1}(P)\right)$ to finance the investment cost. At investment, the equity holders receive a levered equity position denoted by $E_{1}(P)$. The firm has a useful life (firm maturity) $T_{F}$ relative to the first investment stage. After the first investment stage, subsequent investment stages may follow with maturities $T_{i}, i=2,3, \ldots S$ relative to the prior stage (so the maturity horizon for the $i$ option is the accumulated time $T_{1}+T_{2}+\ldots T_{i}$ ). At each investment stage the firm may decide to issue new debt and rebalance its capital structure. ${ }^{5}$ Debt issue $i$ demands a tax-deductible coupon payment $R_{i}$ per period and a

\footnotetext{
${ }^{5}$ We assume that existing debt cannot be repaid early at this stage so the firm has the option only to increase its debt usage.
} 
final principal debt (face value) $F_{i}$ at maturity. Debt maturity for each debt issue is specified by $T_{D_{i}}$ with $T_{D_{1}} \leq T_{F}, T_{D_{2}} \leq T_{F}-\left(T_{1}+T_{2}\right), T_{D_{3}} \leq T_{F}-\left(T_{1}+T_{2}+T_{3}\right)$ etc.

In order to accommodate the choice of different coupon levels at each investment stage, we employ a forward-backward algorithm. The algorithm proceeds by first creating the pre-investment stage tree with $N_{1}$ steps. At each price level at the end nodes of the first investment stage, several lattices are created that capture the next operational phase and default decisions conditional on the choice of the coupon level. Coupon levels at stage $i$ depend on the level of revenues $P_{i}$ at each state which is discretized through the choice of $n_{C}$ points and the use of a maximum of $c_{\max }$ points. This implies the following dynamically created coupon grids:

$$
\text { coupon }_{i}=\left\{0, \frac{1}{n_{c}} \cdot P, \frac{2}{n_{c}} \cdot P, \ldots . \frac{c_{\max }}{n_{c}} P_{i}\right\}
$$

Figure 1 illustrates (using a two-stage example) how the lattice algorithm is applied for multiple investment stages and multiple debt issues. The operational phase is initiated at the time of the first investment maturity $T_{1}$ and is assumed to have duration of $T_{F}$ periods. It may however be terminated if operational costs or coupon payments cause the firm to default (we explain endogenous default decisions in greater detail below). Operations may also be terminated at the subsequent investment stages if the firm decides not to proceed with new investment. At the end of the first investment horizon, a first debt issue can be made. At this stage, the first coupon selection process starts with new lattice trees created. Depending on the maturity of the first debt issue, the coupon payments may continue after the second investment stage (or the third if one exists). At the time of the second investment stage, the firm may decide on a new debt issue. At this 
stage, a new coupon search process will start conditional on the earlier coupon selection. The coupon grid for the second debt issue will depend on the level of revenue reached. Similarly with the first debt issue, the debt maturity of the second option may or may not overlap with other stages and should mature before or at the end of the operational phase of the firm.

\section{[Insert Figure 1 here]}

Investment stages are approximated by lattices with sizes that are defined relative to the tree used for the pre-investment stage, which is used as benchmark. Denoting the pre-investment stage with $N_{1}$, the size of the $i$ subsequent interval $(i=2,3, \ldots)$ will thus be $\quad N_{i}=\left(\frac{T_{i}}{T_{1}}\right) \cdot N_{1}$. The last period (after $T_{S}$ ) is approximated by $N_{F}=\left(\frac{T_{F}-\left(T_{1}+T_{2}+\ldots T_{S-1}\right)}{T_{1}}\right) \cdot N_{1}=\left(\frac{T_{S}}{T_{1}}\right) N_{1}$.

If new investment leads to expansion of revenues, then this is modeled using $e_{1}, e_{2} \ldots e_{S}$ expansion factors multiplying the revenue variable. The revenue level at stage $i$ equals $\left(e_{1}+e_{2} \ldots e_{i}\right)$ times the revenue of that stage. When investments do not expand cash flows the expansion factors will be set to zero with only $e_{1}=1$. In the event of bankruptcy proportional costs $b$ to the value of the firm are incurred. Priority rules for debt holders in case of default need also to be specified. Here both absolute priority (APR) and pari- 
passu (PPR) rules are considered. Under APR of the early debt issues debt holders value $i$ at time $t, D_{i t}$, in case of default is specified by ${ }^{6}$ :

$$
\begin{aligned}
& D_{1 t}=\min \left[(1-b) V_{t}^{u}, R_{1} \Delta t+\tilde{D}_{1 t}\right] \\
& D_{j t}=\min \left[(1-b) V_{t}^{u}-\sum_{i=1}^{j-1} D_{i t}, R_{j} \Delta t+\tilde{D}_{j t}\right], \quad j=2, \ldots . S
\end{aligned}
$$

where $\widetilde{D}_{i t}$ denotes the expected continuation value for debt issue $i$ in case the firm does not default at $t$ calculated as $\tilde{D}_{i t}=\left(p_{u} D_{t+d t, h}+\left(1-p_{u}\right) D_{t+d t, l}\right) e^{-r d t}$. In the case of PPR debt value $j$ in the event of bankruptcy is determined by:

$$
D_{j t}=\left(\frac{D_{j t}}{\sum_{i=1}^{S} D_{i t}}\right) \cdot(1-b) V_{t}^{u}, \quad j=1,2, \ldots S .
$$

A standard formulation of the lattice parameters for the up and down jumps and the up and down probabilities (see Cox, Ross and Rubinstein, 1979) requires that $u=e^{\text {odt }}$, $d=e^{-\sigma d t}=\frac{1}{u}, p_{u}=\frac{e^{(r-\delta) d t}-d}{u-d}, p_{d}=1-p_{u}$, where $d t=\frac{T_{F}}{N_{F}}, \delta$ is an opportunity cost parameter and $r$ denotes the interest rate, which is employed for discounting. We keep track of the following information at each node of the binomial tree: unlevered assets

\footnotetext{
${ }^{6}$ More formally, the above rule defines a first-come/first-serve rule where the priority is defined by the debt issue which came first.
} 
$\left(V^{U}\right)$, tax benefits of debt $(T B)$, bankruptcy costs ( $\left.B C\right)$, equity $(E)$, debt issues $\left(D_{1}, D_{2}, \ldots\right)$ and levered firm value $\left(V^{L}\right)$.

Cash inflows (revenues) and outflows (costs and interest payments), as well as default or continuation decisions, occur every time step $\Delta t . \Delta t$ can be controlled by a variable $N_{d e c}$ that specifies the number of decision points within each unit period. ${ }^{7}$ Let the corporate tax rate be denoted by $\tau>0$. We describe the model under the full loss offset tax scheme. Under a no loss scheme firms do not pay any taxes unless the earnings after interest payments is positive (see also Leland, 2007). Results are not materially changed under the no loss scheme. At the end of the operational phase $T_{F}$ equity and the other variables are calculated as follows:

$$
E_{T_{F}}=\max \left[\left(P_{T_{F}}-C-\sum_{i=1}^{S} R_{i} I_{i}^{d e b t}\right)(1-\tau) \Delta t-\sum_{i=1}^{S} F_{i} I_{i}^{d e b t}, 0\right]
$$

where $I_{i}^{\text {debt }}$ is an indicator that takes the value 1 if debt issue $i$ has not expired and zero otherwise. $^{8}$

If $E_{T_{F}}>0$, then

$$
\begin{aligned}
& V_{T_{F}}^{u}=\left(P_{T_{F}}-C\right)(1-\tau) \Delta t \\
& T B_{T_{F}}=\tau\left(\sum_{i=1}^{S} R_{i} I_{i}^{d e b t}\right) \Delta t
\end{aligned}
$$

\footnotetext{
${ }^{7}$ Thus, $\Delta t=1 /$ Ndec. Each $\Delta t$ interval is approximated by a sub-tree $N_{\Delta t}$. To maintain accuracy discounting occurs for the interval $d t=T_{i} / N_{i}$. In principle, the decisions can be made as dense as possible approximating the continuous decision limit when $\mathrm{N}_{\mathrm{dec}}$ tends to infinity.

${ }^{8}$ This requires that we keep track of elapsed time for each debt issue.
} 


$$
\begin{aligned}
& B C_{T_{F}}=0 \\
& D_{i T_{F}}=R_{i} \Delta t+F_{i} \\
& V_{T_{F}}^{L}=E_{T_{F}}+\sum_{i=1}^{S} D_{i} I_{i}^{d e b t},
\end{aligned}
$$

otherwise if $E_{T_{F}}=0^{9}$ (i.e., bankruptcy occurs):

$$
\begin{aligned}
& V_{T_{F}}^{u}=\left(P_{T_{F}}-C\right)(1-\tau) \Delta t \\
& T B_{T_{F}}=0 \\
& B C_{T_{F}}=b V_{T_{F}}^{u} \\
& V_{T_{F}}^{L}=E_{T_{F}}+D_{T_{F}} .
\end{aligned}
$$

Debt values at maturity in the event of default depend on the priority rule. In the case of APR:

$$
\begin{aligned}
& D_{1 T_{F}}=\min \left[(1-b) V_{T_{F}}^{U}, R_{1} \Delta t+F_{1}\right\rfloor \\
& D_{j T_{F}}=\min \left[(1-b) V^{u}-\sum_{i=1}^{j-1} D_{i T_{F}}, R_{j} \Delta t+F_{j}\right], j=2, \ldots . S
\end{aligned}
$$

In the case of PPR:

$$
D_{i, T_{F}}=\left(\frac{D_{i, T_{F}}}{\sum_{i=1}^{S} D_{i T_{F}}}\right) \cdot(1-b) V_{T_{F}}^{U}
$$

\footnotetext{
${ }^{9}$ If the value of unleveled assets turns negative then the value of all variables are set to zero.
} 
Prior to the maturity of the operational phase (and after all investments have taken place) the values of each of these variables are calculated as follows:

$$
E_{t}=\max \left[\left(P_{t}-C-\sum_{i=1}^{S} R_{i} I_{i}^{\text {debt }}\right)(1-\tau) \Delta t+\tilde{E}_{t}, 0\right]
$$

If $E_{t}>0$, then

$$
\begin{aligned}
& V_{t}^{u}=\left(P_{t}-C\right)(1-\tau) \Delta t+\tilde{V}_{t}^{u} \\
& B C_{t}=0+\tilde{B C} C_{t} \\
& T B_{t}=\tau\left(\sum_{i=1}^{S} R_{i} I_{i}^{d e b t}\right) \Delta t+\tilde{T B_{t}} \\
& D_{i t}=R_{i} \Delta t+\tilde{D}_{i, t} \\
& V_{t}^{L}=E_{t}+\sum_{i=1}^{S} D_{i t} I_{i}^{d e b t},
\end{aligned}
$$

whereas, if $E_{t}=0$ then

$$
\begin{aligned}
& V_{t}^{u}=\left(P_{t}-C\right)(1-\tau) \Delta t+\tilde{V}_{t}^{u} \\
& B C_{t}=b V_{t}^{u} \\
& T B_{t}=0 \\
& V_{t}^{L}=E_{t}+\sum_{i=1}^{S} D_{i t} I_{i}^{\text {debt }},
\end{aligned}
$$


where $\tilde{x}_{t}$ denotes the expected discounted value of variable $x$ and equals $\tilde{x}_{t}=\left(p_{u} x_{t+d t, h}+\left(1-p_{u}\right) x_{t+d t, l}\right) e^{-r d t}$. Debt values are determined similarly depending on the priority structure. Under APR expression (1a) can be applied, while for the case of PPR one would use equation (1b) for each debt value. For points within the lattice not involving a decision to default or not, which are used for increased accuracy, the values of each variable are the discounted expected values of the variables of the following period.

At the maturity of each investment option stage $i$ occurring at time $t$, where $t$ takes values according to the specified investment maturities, the levered firm value includes the equity value plus the amount of debt received at $i$ plus the expected present values of debt raised in the future minus the total cost which includes the investment paid at stage $i$ and the expected present value of the costs to be paid in the future:

$$
\begin{aligned}
V_{t}^{L} & =\max \left[E_{t}+D_{i t}+\sum_{k=i+1}^{S} \tilde{D}_{k t}-\left(I_{i}+\sum_{k=i+1}^{S} \tilde{I}_{k}\right), 0\right] \\
& =\max \left[V_{t}^{u}+T B_{t}-B C_{t}-\left(I_{i}+\sum_{k=i+1}^{S} \tilde{I}_{k}\right), 0\right]
\end{aligned}
$$

By recursively applying expression (4) at each investment stage $i$, all investment stages are optimized. Expression (4) takes into account the current value of equity $E_{t}$ and debt $D_{i t}$ and the current investment costs $I_{i}$. The current value of equity and debt takes into account the future optimization by equity holders of the default trigger as can be seen by expressions (3a) and (3b). The present value of future debt issues (denoted by $\sum_{k=i+1}^{S} \widetilde{D}_{k t}$ ) is in expected terms (i.e., it is a probability weighted of each of the future debt values) and 
thus considers the possibility of default and that some or all of the future investment options will not be exercised. Similarly, the term $\sum_{k=i+1}^{S} \tilde{I}_{k}$ denotes the expected present value of investment costs and thus takes into account the future optimization of investment stages.

For example, in the first investment stage and assuming two stages only, the condition at the maturity of the investment stage would be:

$$
\begin{aligned}
V_{T_{1}}^{L} & =\max \left[E_{T_{1}}+D_{T_{1}}+\widetilde{D}_{T_{2}}-I_{1}-\tilde{I}_{2}, 0\right] \\
& =\max \left[V_{T_{1}}^{u}+T B_{T_{1}}-B C_{T_{1}}-I_{1}-\tilde{I}_{2}, 0\right]
\end{aligned}
$$

while at the second stage the condition at investment becomes:

$$
\begin{aligned}
V_{T_{2}}^{L} & =\max \left[E_{T_{2}}+D_{T_{2}}-I_{2}, 0\right] \\
& =\max \left[V_{T_{2}}^{u}+T B_{T_{2}}-B C_{T_{2}}-I_{2}, 0\right]
\end{aligned}
$$

Bankruptcy in periods between investment stages (and prior to the final investment) is triggered when the earnings net of cost and coupon payments plus the expected levered firm value (which includes expected equity value, expected cash received by debt issues and expected costs to be paid) are negative. Thus, the bankruptcy condition for any time $t$ prior to the last investment stage is:

$$
V_{t}^{L}=\max \left[\left(P_{t}-C-\sum_{i=1}^{I} R_{i} I_{i}^{d e b t}\right)(1-\tau) \Delta t+\tilde{V}_{t}^{L}, 0\right]
$$


If $V_{t}^{L}>0$ then the values at that stage are calculated as in expressions (3a) and (3b) while in case of bankruptcy using equations (3c) and (1a) (or 1b in the case of PPR).

The values at $t=0$ are obtained by maximizing expression (5) using an exhaustive forward-backward search procedure that evaluates all combinations of coupons at the different stages and states of the revenue variable. The optimal value of the firm at time zero involves the sum of the expected present value of equity, the expected present value of all debt issues minus the expected present value of the investment costs. This is equivalent to the expected present value of the unlevered assets plus the expected present value of the tax benefits minus the expected present value of bankruptcy and the investment costs. Finally, in order to evaluate leverage ratios, the proportion of initial debt value over firm value (adding back investment costs) can be calculated (Lev $)$.

\section{Numerical results and discussion}

\subsection{Long term debt}

In this section we investigate the case of long term debt where the early debt issue horizon interacts with the subsequent debt issue. In all numerical simulations we adopt APR of the first debt issue. Results are not materially altered with PPR, with only slight increases in the second debt issue value. ${ }^{10}$

\footnotetext{
10 In general, our investigation reveals that firm values exhibit small oscillations between small and larger number of lattice steps. This is particularly important since the differences between 12 and 24 steps do not exceed 3.6\% and are not affected by the volatility used (results available upon request). As pointed out by the analysis of Broadie and Kaya (2007) and Agliardi and Koussis (2011) working with lattice models in a similar context debt values and leverage ratios exhibit larger oscillations. As pointed out in these papers debt values are oscillatory because the approximation of the
} 
In Table 1 we first observe a U-shape pattern of firm values as a function of volatility for relatively out-of-the-money options. ${ }^{11}$ This result is due to the trade-offs involved: a higher volatility increases the option value on unlevered assets (defined as the difference between VU and Inv2 in the table) but reduces the net benefits of debt (tax benefits minus bankruptcy costs). This result is similar to the one-stage investment problem with one debt issue (e.g., Mauer and Sarkar, 2005). If the firm's revenue levels are high (in-the-money case), then an increase in volatility not only hurts the net benefits of debt, but also increases the probability of ending up in the out-of-the-money range, resulting in a monotonic decrease in firm value.

\section{[Insert Table 1 here]}

It is a well-known result that a low volatility enhances debt values when the firm is at the investment trigger and no future investment stages follow (see for example, Leland, 1994). However, in the multistage investment setting analyzed here, the first debt issue increases with volatility (see the out-of-the-money case) since another investment stage follows. Furthermore, the initial debt expires after the maturity of the second investment stage, which creates an option effect. As a result, an increase in volatility results in the firm borrowing more heavily initially since the option value of repaying the remaining

default boundary is particularly important. Our approach based on sub-lattices emerging from each end note of a particular investment and financing stage shows similarities with an adaptive mesh approach (see Figlewski and Gao,1999) which improves the accuracy in barrier options and allows us to draw important conclusions discussed below.

${ }^{11}$ We loosely define moneyness by comparing firm values in the case $P=10$ and $P=30$. One can calculate the implied value of unlevered assets (without default). When $P=10$ then $V=10(1-0.35) / 0.06=108.33$ while $V=30$ (1$0.35) / 0.06=325$ when $\mathrm{P}=30$. The investment costs add up to 100 . Thus the expressions "out-of-the-money" -“in-themoney" refer to the case where the firm is less likely - more likely - to exercise its investment options. In our example, $\mathrm{P}=30$ describes the "in the money" case, while $\mathrm{P}=10$ the "out-of-the money" case. 
debt (and obtaining remaining tax benefits net of bankruptcy costs) is now higher. This option effect is more important for the low revenue (out-of-the-money) case since a higher volatility makes the option ending up in-the-money more likely. We also observe that initial coupon levels are also increasing in volatility for the out-of-the-money case.

On the other hand, when initial revenues are high (the option is more in-the-money), a low volatility implies a lower bankruptcy risk, while also maintaining a high probability that the option stays in-the-money. This allows the firm to borrow more heavily at low volatility levels and thus as the volatility increases debt levels and leverage decrease. However, at high volatility levels the option effect highlighted above appears to dominate and thus we have an increase in initial debt levels and leverage Interestingly, coupon levels also have a U-shape for the high revenue case. This U-shape holds also in Leland (1994) in the absence of growth options. In sum, with respect to leverage ratios, we observe that the proportion of the initial debt in firm value as described by $\operatorname{Lev}_{1}$ is increasing in volatility for low revenue (out-of-the-money options) and may have a Ushape for high revenue (in-the-money options).

An increase in volatility causes a decrease in second debt values since there are no more stages remaining which would create a similar option effect as in the case of initial debt issue. Simulations also show that a higher volatility results in a decrease in the probability of exercising the second stage investment. This is indicated by the lower expected present value of the second stage costs, which decrease for both the out-of-themoney and the in-the-money case. 
Additional sensitivity analysis is also conducted with respect to other model parameters. Table 2 shows sensitivity results with respect to the opportunity cost $\delta$, the expansion factor $e_{2}$ and the investment cost of the second stage $I_{2}$.

[Insert Table 2 here]

Panel A shows that a higher competitive erosion parameter $\delta$ (i.e., lower revenue growth) results in a reduction in firm value and lower debt levels used both at the initial and the second stage. Leverage ratios are slightly decreasing in the level of the competitive erosion parameter $\delta .^{12}$ Panel $\mathrm{B}$ shows that a higher expansion factor $e_{2}$ for the second stage investment results in an increase in firm value and an increase in the initial and subsequent debt values. Lev 1 presents a U-shape in the expansion factor $e_{2}$. Panel C shows sensitivity with respect to the level of the second stage investment cost $I_{2}$. A higher second stage investment cost $I_{2}$ results in a decrease in firm values. The initial debt levels decrease when the investment cost is low but at higher levels of the investment cost the initial debt level may even exhibit an increase. The U-shape of leverage with respect to growth options implies that for relatively low growth options the higher risk levels enhance equity values more than debt and as the options become more in-the-money the lower risk levels following the exercise of a high growth option enhance debt and leverage. Hackbarth and Mauer (2012) have shown a similar result using a perpetual horizon for debt.Our analysis differs in two main aspects. First, our analysis allows for finite debt horizon and secondly we fix investment timing whereas Hackbarth and Mauer

12 The small decreases in leverage ratios at high levels of $\delta$ also appear also in the Leland (1994) nogrowth framework. Due to the numerical nature of the solution these decreases are hard to capture for the higher levels of $\delta$ in which case our numerical solution shows that leverage ratios are almost unchanged. 
(2012) allow equity holders to select the timing of investment. In the absence of investment timing, we similarly find a U-shape in the case of multiple debt issues outstanding with finite long-term maturity. Our analysis with finite debt maturities allows us to investigate other possible cases that are not possible in the Hackbarth and Mauer (2012) setting. As it is shown in the subsequent section the U-shape relationship between leverage and growth options does not appear in the case of short-term debt issues which have no interaction in their debt horizons. In that case a negative relationship between growth options and leverage prevails. Hackbarth and Mauer (2012) analysis has shown that a negative relationship between growth options and leverage may appear when there are agency conflicts between debt and equity holders. Our result shows an additional factor where such a negative relationship may be possible in the absence of agency conflicts when debt maturity is short-term.

\subsection{Short term debt}

In this subsection we focus on the short term debt case. Table 3 presents sensitivity results with respect to volatility for the unconstrained case with short debt maturity for both debt issues $\left(\mathrm{TD}_{1}=\mathrm{TD}_{2}=5\right)$. For the short term debt case, we observe that the firm optimally selects high coupon levels which exceed current revenue levels. This implies that debt financing constraints may become more binding. We also observe that initial equity value (net worth) is negative (seen as the difference between firm value and the sum of debt net of the present value of investment costs). This is because of the high coupon and debt levels. Firm values are higher than the long term debt case for all levels 
of volatility and for different levels of moneyness. This is confirmed in further detailed tests of debt maturity choice we performed, which show that short term debt is optimal for both debt issues. It is also in keeping with an earlier result of Agliardi and Koussis (2013) for a single debt issue, showing that for bank loans (with no principal payment) short term maturity is preferred. In contrast, when principal is due, long-term maturity for debt is optimal (see also Leland and Toft, 1996). This is also consistent with empirical evidence by Altman, Gande and Saunders (2010) and Rauh and Sufi (2008), who find that loans have typically shorter maturity than bonds, and McKay (2003) who finds that firms relying more on shorter term loans have higher leverage (although he relates this to agency reasons).

[Insert Table 3 here]

In contrast to the long term case, we observe that the U-shape in firm value with respect to volatility for the low revenue (out-of-the-money) case does not appear. Indeed, with short term debt the firm value is higher (more in-the-money) for the same level of revenue, and so a decreasing relationship between volatility and the firm value is observed (similar to the in-the-money case for long term debt). Now debt values are strictly decreasing in volatility. Despite the decrease in debt values, we still observe, like in the case of long-term debt, that the coupon level and leverage ratios $\left(\operatorname{Lev}_{1}\right)$ are increasing in volatility for the low revenue (out-of-the-money option) case. Finally we observe that since now the initial debt expires before the exercise of the second stage investment, there are no remaining net benefits accruing and thus the above mentioned 
option effect relates to the unlevered assets only (indeed, the value of unlevered assets net of the expected investment cost of stage 2 is increasing in volatility).

For the in-the-money case we observe that the negative relationship between firm value with volatility remains. Furthermore, we now observe coupon values that are decreasing in volatility and leverage ratios are decreasing in volatility (no U-shape appears as in the case of long-term debt). One can observe that high coupon values often exceeding double the value of current revenue levels $(\mathrm{P}=30)$. Thus, such high coupon levels may not be realistically possible in practice (our analysis in the following section explores this issue further by exploring financing constraints).

We also summarize sensitivity results with respect to the other parameters. Similarly to the long-term debt case an increase in the level of competitive erosion $\delta$ results in a decrease in the use of initial and subsequent debt and a reduction in firm value (results not shown for brevity). An increase in the expansion factor $e_{2}$ results in an increase in firm value and in the initial and subsequent debt levels. Interestingly however, and in contrast to the case of long term debt case, $\operatorname{Lev}_{1}$ is strictly decreasing in the level of the expansion factor $e_{2}$ as it is shown in Figure 2

[Insert Figure 2 here]

Our numerical results have also shown (also not shown for brevity) that a higher level of the investment cost $I_{2}$ results in a reduction in firm value and the use of both initial and subsequent debt levels and a strictly decreasing leverage ratio $\left(\operatorname{Lev}_{1}\right)$. 
Thus, in contrast to the long-term case where debt maturities interact, an increase in the value of growth options (increase in the expansion factor or decrease in growth option investment costs) increases equity more than debt resulting in a decrease in leverage ratios. This result appears in line with the argument of Myers (1977) that short-term debt may alleviate underinvestment and thus enhance the value obtained by equity holders since equity holders have more flexibility in optimizing their capital structure depending on the prospects of their growth options. This allows equity holders to increase debt in absolute terms; however, the value increase in equity reduces leverage ratios.

Table 4 provides a summary of model main predictions in the case of no financing constraints about firm value and leverage.

[Insert Table 4 here]

\subsection{The effect of financing constraints}

In this section we investigate the effect of financing constraints. Debt constraints are modeled by limiting the possible coupon level at each borrowing date to be a fraction of the revenue level at the time of debt issue. This is a particularly reasonable assumption especially for bank loans since banks normally take into consideration that the coupon (installment) is only a fraction of the revenue level to limit liquidity risk and default. We

thus define debt financing constraints by setting $c_{\max }<c_{\text {points }}$ thus limiting the possible 
level of coupon at the time of debt issuance (see the expression in section 2 defining coupon grids).

The modeling of equity financing constraints is more involved. First, note that in the unconstrained case, the bankruptcy trigger decision between investments stages described in expression (5) allows that equity value between stages becomes negative, implying the possibility of a negative equity net worth. In these stages, equity holders base their decision on the total levered firm value that includes the expected value of debt raised at the next debt issue. ${ }^{13}$ With no constraints on equity net worth, equity holders may optimally choose to continue even if the component reflecting the value of equity is negative. After the final investment is completed the model becomes similar to Leland (1994) in that equity holders will only continue if equity is positive (since there is no ability to raise more debt in the future). We investigate the case where equity holders face constraints where equity net worth remains non-negative at all times, i.e., $E_{t} \geq 0$. We note that this condition differs from the equity financing constraints of Yang (2011). Our condition still allows that equity holders finance part or all of the investment cost at the time investments take place. This condition also allows the infusion of cash by equity holders, which implies equity dilution is still possible (see also Broadie and Kaya, 2007, Proposition 1) in the in-between investment stages. However, equity infusion in the case of non-negative equity net worth constraints can only occur if the condition of positive net worth is satisfied, otherwise default is triggered. This type of constraints may reflect difficulties in raising new external finance in the case where the firm is not performing well (see for example, Hubbard and Kashyap, 1992).

\footnotetext{
${ }^{13}$ This approach corresponds to Hackbarth and Mauer (2012) (see also Mauer and Sarkar, 2005) first-best approach of total firm value maximization that does not consider agency problems between equity and debt holders.
} 
Sensitivity results are presented only for the short-term case, where the selected high initial coupon levels make equity net worth constraints more prevalent. Our goal is to investigate whether the presence of this type of financing constraints can have an important impact on firm values so as to induce the firm to choose long term instead of short term debt which as we have shown appears the preferred choice in the absence of constraints.

Table 5 shows sensitivity results with respect to volatility when the firm faces non-negative equity net worth constraints. We first observe that despite the negative impact on firm values of non-negative equity net worth constraints (compared to the unconstrained values of Table 3), firm values remain larger than the long term case (Table 1). Thus, non-negative equity net worth constraints may be insufficient in justifying the use of long term debt.

We also observe some new results with respect to volatility. For both the low initial revenue (out-of-the-money) and the high initial revenue (in-the-money) cases, an increase in volatility reduces firm values by reducing the value of unlevered assets and the tax benefits of debt.

Under non-negative net worth constraints, firms issue less debt initially in order to avoid distress and thus behave conservatively (compare initial leverage levels with the unconstrained case of Table 3). This is consistent with the empirical observation that firms with growth opportunities are not highly leveraged (Graham, 2000, Billett et al., 2007 and DeAngelo et al., 2010), providing a possible explanation for the conditions under which growth firms borrow conservatively. 
[Insert Table 5 here]

Table 6 shows the results in the presence of debt financing constraints. Under a moderate constraint, where coupon levels cannot exceed $75 \%$ of revenue levels at each debt issue, we find that debt constraints for both the low revenue (out-of-the-money) and the high revenue (in-the-money) cases are binding, resulting in the maximum allowable coupon being used. Firm values are significantly reduced compared to the unconstrained case of Table 3. With stricter debt financing constraints firm values become smaller than with long term debt (Table 1), thus justifying the use of long term debt.

The following observations regarding volatility also arise. In the low revenue case, an increase in volatility increases firm value. This result is caused by an increase in the option value of unlevered assets (value of unlevered assets net of expected costs). In this case a higher volatility helps alleviate the impact of financing constraints by countering the reduction in the tax benefits of debt with an increase in option value on unlevered assets. Our results regarding volatility, firm values and investment have important implications for empirical studies relating volatility with investments (e.g., Caballero and Pindyck, 1996, and Leahy and Whited, 1996). As pointed out in Boyle and Guthrie (2003), the debate on the sensitivity of investments to volatility and firm financial constraints has often inconclusive empirical results. ${ }^{14}$ Our model provides an avenue for understanding these inconclusive results. First, even in the unconstrained case, we show that for firms with long-term debt and low profitability a U-shape may exist between

\footnotetext{
${ }^{14}$ See also Fazzari, Hubbard and Petersen (1988), (2000) and Kaplan and Zingales (2000). Boyle and Guthrie (2003) suggest that liquidity (financing) uncertainty interacting with payoff uncertainty may be the cause of these inconclusive results.
} 
volatility and firm value, whereas for short term debt or/and high revenue firms there is negative relationship. Furthermore, our analysis of constrained firms shows that for equity net-worth constrained firms an increase in volatility results in a decrease in firm values and thus investment, whereas for debt financing firms an increase in volatility enhances firm value.

[Insert Table 6 here]

Further observation of Table 6 also reveals that both the initial and subsequent debt values are decreased but $\mathrm{Lev}_{1}$ remains rather flat as a function of volatility.

In the high revenue case, an increase in volatility has little impact on firm value when the firm faces debt financing constraints. This occurs because both the value of unlevered assets and the net benefits of debt remain rather unaffected by volatility.

In comparison with the unconstrained case, the percentage drop in value is more substantial for the low revenue firms. Furthermore, debt financing constraints at this plausible level of constraints (where coupons cannot exceed $75 \%$ of the revenue levels at the time of the new debt issue) appear more significant than equity positive net worth constraints. This is in line with Yang (2011) who finds empirical support of a stronger impact of debt financing constraints. Overall, the prevalence of these financing constraints are expected to be more severe in times of crises which drive firm revenues down and reduce available external financing. Thus, our framework provides important insights on the effect and significance of the impact of financing constraints on firm 
values and the economic activity. The significant impact of debt financing constraints also provides a plausible justification for the use of long-term debt.

\section{Conclusion}

One of the main implications of this paper is to use a dynamic investment options model to show that firm value is maximized when debt maturity is short. However, with short term debt firms would optimally borrow more heavily and are thus more likely to face financing constraints compared with long term debt. We investigate the plausible explanation of firms using long term debt due to non-negative equity net worth constraints and debt constraints. We show that debt financing constraints have a more significant impact on firm values compared to non negative equity net worth constraints, thus providing a more plausible explanation for firms using long term debt to alleviate these constraints.

The paper also produces some interesting implications on the effect of volatility on firm values and corporate capital structure. With long term debt expiring after the maturity of investment stages, we show that volatility may actually enhance leverage. We explain that this is due to an option value of obtaining tax benefits accruing following an investment stage. Firm values may follow a U-shape with volatility, a result that confirms other literature results employing a single investment stage. Furthermore, volatility may actually enhance firm values in the presence of debt financing constraints. However, in the presence of non-negative equity net worth constraints, an increase in volatility hurts firm value. 


\section{References}

Agliardi, E., Koussis, N., 2013. Optimal Capital Structure and the Impact of Time-tobuild. Financ Res Lett 10, 124-130.

Altman, E., Gande, A., Saunders, A., 2010. Bank Debt vs Bond Debt: Evidence from Secondary Market Prices. J Money Credit Bank 42, 755-767.

Barclay, M. J., Smith, C.W.1995. The Maturity Structure of Corporate Debt. J Financ 50: 609-631.

Bhagat, S., Bolton, B., Subramanian, A., 2011. Manager Characteristics and Capital Structure: Theory and Evidence. J Financ Quant Anal 46: 1581. Billett, M.T., King, T.H.D., Mauer, D.C., 2007. Growth Opportunities and the Choice of Leverage, Debt Maturity and Covenants. J Financ, 62, 697-730.

Boyle, G. W., Guthrie, G.A., 2003. Investment, Uncertainty, and Liquidity. J Financ 58, 2143-2166.

Broadie, M., Kaya, O., 2007. A Binomial Lattice Method for Pricing Corporate Debt and Modeling Chapter 11 Proceedings. J Financ Quant Anal 42, 279-312.

Caballero, R., Rindyck, R., 1996. Uncertainty, Investment, and Industrial Evolution. Int Econ Rev 37, 641-662.

Campello, M, Graham, J.R., Harvey, C.R., 2010. The Real Effects of Financial Constraints: Evidence from a Financial Crisis. J Financ Econ 97, 470-487.

Cleary, S., Povel, P., Raith, M., 2007. The U-Shaped Investment Curve: Theory and Evidence. J Financ Quant Anal 42, 1-40. 
Cox, J.C., Ross, S.A., Rubinstein, M., 1979. Option Pricing: a Simplified Approach. J Financ Econ 7, 229-263.

DeAngelo, H., DeAngelo, L., Whited, T.M., 2011. Capital Structure Dynamics and Transitory Debt. J Financ Econ 99, 235-261.

Fan, J. PH, Titman, S. Twite, G. 2012. An International Comparison of Capital Structure and Debt Maturity Choices. J Financ Quant Anal 47: 23-56.

Fazzari, S., Hubbard, G.R., Petersen, B., 1988. Finance Constraints and Corporate Investment. Brookings Pap Eco Ac 141-195

Fazzari, S., Hubbard, G.R., Petersen, B., 2000. Investment-cash flows Sensitivities are useful: a Comment on Kaplan and Zingales. Q J Econ 115, 695-706.

Figlewski, S., Gao, B. 1999. The adaptive mesh model: a new approach to efficient option pricing. J Financ Econ 53, 313-351.

Gomes, J. F., Yaron, A., Zhang, L., 2006. Asset Pricing Implications of Firms’ Financing Constraints. Rev Financ Stud 19, 1321-1356.

Graham, J. R., 2000. How Big Are the Tax Benefits of Debt? J Financ 55, 1901-1941.

Hackbarth, D., Mauer, D.C., 2012. Optimal Priority Structure, Capital Structure and Investment. Rev Financ Stud 25, 747-796.

Hirth, S., Uhrig-Homburg, M., 2010. Investment Timing, Liquidity, and Agency Costs of Debt. J Corp Financ 16, 243-258.

Hubbard, G., Kashyap, A.K., 1992. Internal Net Worth and the Investment Process: An Application to U.S. Agriculture. J Polit Econ 100, 506-534.

Hubbard, G., Kashyap, A. K., Whited, T.M., 1995. Internal Finance and Firm Value. J Money Credit Bank 27, 683-701. 
Hugonnier, J., Malamud, S., Morellec, E., 2012. Capital Supply Uncertainty, Cash Holdings and Investment, EPFL Seminar series.

Ju, N., H.Ou-Yang, H. 2006. Capital Structure, Debt Maturity, and Stochastic Interest

Rates J Bus 79: 2469-2502.

Leahy, J. V., Whited, T.M., 1996. The Effects of Uncertainty on Investment: Some Stylized Facts. J Money Credit Bank 28, 64-83

Lemmon, M.L., Zender, J.F., 2010. Debt Capacity and Tests of Capital Structure. J Financ Quant Anal 45, 1161-87.

Kaplan, S.N., Zingales, L., 2000. Investment-cash flows sensitivities are not valid Measures of Financing Constraints. NBER WP 7659

Kiyotaki, N., Moore, J., 1997. Credit Cycles. J Polit Econ 105, 211-248.

Koussis, N., Martzoukos, S., 2012. Investment Options with Debt-Financing Constraints. Eur J Financ 18, 619-637.

Leland, H., 1994. Corporate Debt Value, Bond Covenants, and Optimal Capital Structure. J Financ 49, 1213-1252.

Leland, H., 2007. Financial Synergies and the Optimal Scope of the Firm: Implications for Mergers, Spinoffs, and Structured Finance. J Financ 62, 765-807.

Leland, H., Toft, K.F., 1996. Optimal Capital Structure, Endogenous Bankruptcy and the Term Structure of Credit Spreads. J Financ 51, 987-1019.

Lensik, R. , Sterken, E., 2002. The Option to Wait to Invest and Equilibrium Credit Rationing. J Money Credit Bank 34, 221-225.

Mauer, D.C., Sarkar, S., 2005. Real Options, Agency Conflicts and Optimal Capital Structure. J Bank Financ, 29, 1405-1428. 
McKay, P., 2003. Real Flexibility and Financial Structure: an Empirical Analysis. Rev Financ Stud 16, 1131-1165.

Morellec, E., 2001. Asset Liquidity, Capital Structure and Secured Debt. J Financ Econ 61, 173-206.

Myers, S. C. 1977. Determinants of corporate borrowing. J Financ Econ 5: 147-175.

Rauh, J. D., 2006. Investment and Financing Constraints: Evidence from the Funding of Corporate Pension Plans. J Financ 61, 33-71.

Rauh J.D., Sufi, A., 2008. Capital structure and Debt Structure. NBER, WP 14488, http://www.nber.org/papers/w14488.

Schiantarelli, F., 1996. Financial constraints and investment: methodological issues and international evidence. Oxford Rev Econ Pol 12, 70-89.

Sundaresan, S., Wang, N., 2007. Dynamic Investment, Capital Structure, and Debt Overhang. Working Paper. Columbia University.

Titman, S., Tompaidis, S., Tsypliakov, S., 2004. Market Imperfections, Investment Flexibility, and Default Spreads. J Financ 59, 165-205.

Uhrig-Homburg, M., 2005. Cash-Flow Shortage as an Endogenous Bankruptcy Reason. J Bank Financ 29, 1509-1534.

Whited, T.M., 1992. Debt, Liquidity Constraints and Corporate Investment: Evidence from Panel Data. J Financ 47, 1425-60.

Whited, T. M., Wu, G., 2006. Financial Constraints Risk. Rev Financ Stud 19, 531-559.

Yang, J., 2011. Financing Constraints and Capital Structure.Working Paper. 
Figure 1: A graphical illustration of the forward-backward algorithm for multistage investment issues with multiple debt issues

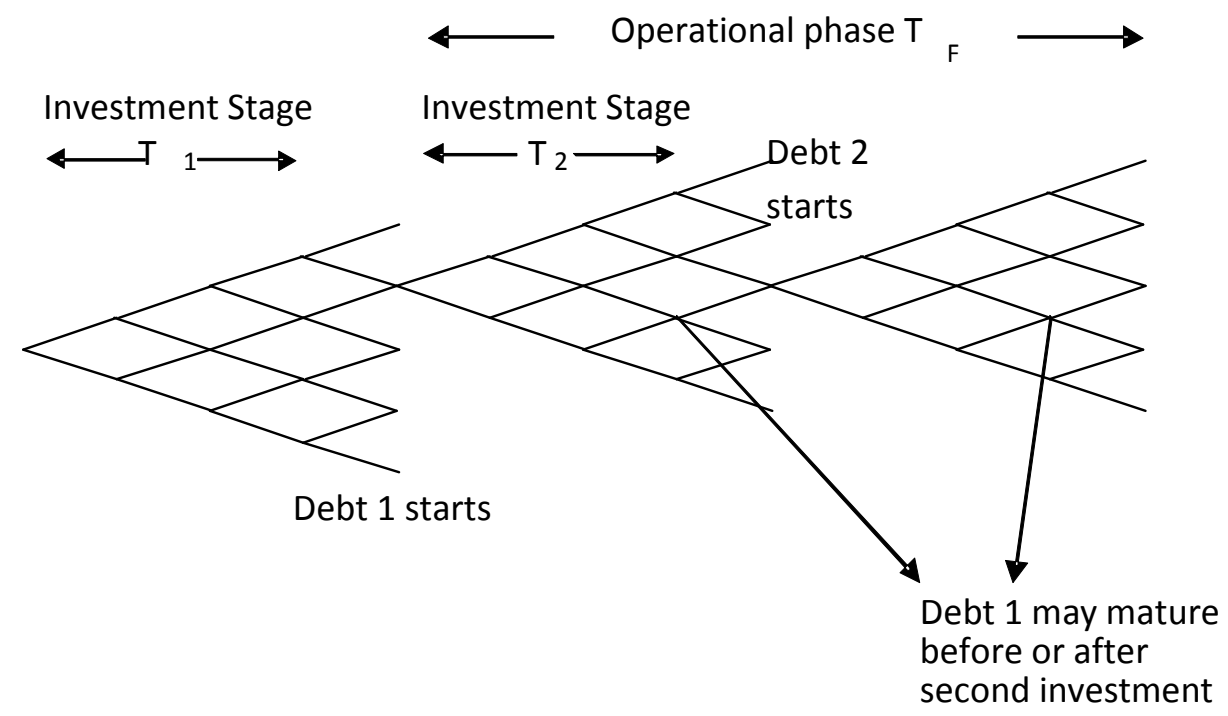

Figure 2: Leverage ratio and growth options: short term debt

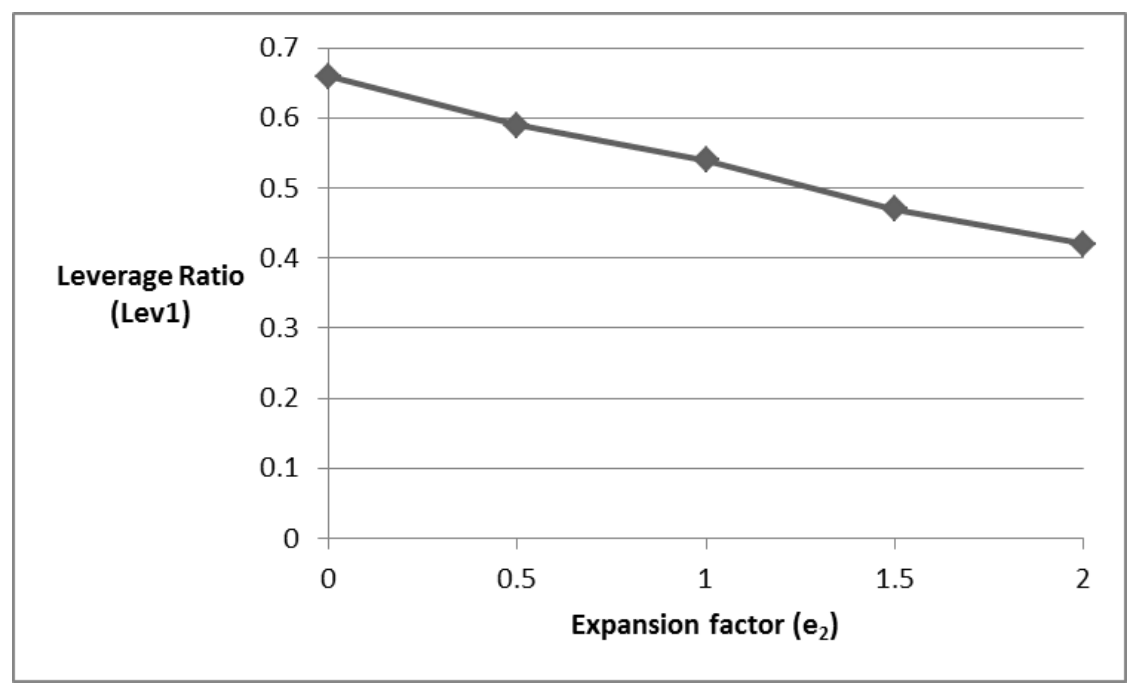

The model with no equity or debt constraints is used. Base case parameters are: $P=10, \mathrm{C}=0$, risk-free rate $r=0.06$, volatility $\sigma=0.2$, competitive erosion $\delta=0.06$, investment cost $I_{1}=50, I_{2}=50, b=0.5$, tax rate $\tau=0.35$ and $\mathrm{T}_{1}=0$, $\mathrm{T}_{2}$ $=5$ (time of second option relative to the first), $\mathrm{T}_{\mathrm{F}}=20$ and debt maturity $\mathrm{T}_{\mathrm{D} 1}=5$ and $\mathrm{T}_{\mathrm{D} 2}=5$ assuming zero principal. An optimal coupon is chosen based on $n_{c}=20$ discretization points for each price level with maximum coupon level points being equal to twice the price levels $\left(c_{\max }=40\right.$ ). In all tables $\mathrm{N}_{\mathrm{dec}}=1$ (yearly decisions) with $\mathrm{N}_{\Delta \mathrm{t}}=24$ steps per year. Initial $(t=0)$ expansion factor $e_{1}=1$ (no expansion) and second stage expansion factor e2 is varied in the numerical simulations. 
Table 1. Long-term debt with debt interactions: Sensitivity to volatility

Low revenue ( $\mathrm{P}=10$ ) (Out-of-the-money case)

\begin{tabular}{|c|c|c|c|c|c|c|c|c|c|c|}
\hline & Firm & vu & TB & BC & Debt 1 & Debt 2 & Inv1 & Inv2 & Coupon $_{1}$ & $\operatorname{Lev}_{1}$ \\
\hline$\sigma=0.10$ & 11.431 & 77.510 & 19.580 & 1.385 & 17.557 & 39.772 & 50 & 34.273 & 1.5 & 0.18 \\
\hline$\sigma=0.20$ & 8.122 & 64.171 & 14.948 & 1.743 & 24.712 & 19.738 & 50 & 19.254 & 3 & 0.32 \\
\hline$\sigma=0.30$ & 9.852 & 62.883 & 13.999 & 2.094 & 24.921 & 17.169 & 50 & 14.937 & 3.5 & 0.33 \\
\hline$\sigma=0.40$ & 13.131 & 61.555 & 15.728 & 3.466 & 33.889 & 14.514 & 50 & 10.686 & 6 & 0.46 \\
\hline
\end{tabular}

High revenue ( $\mathrm{P}=30$ ) (In-the-money case)

\begin{tabular}{clccccccccc} 
& Firm & VU & TB & BC & Debt 1 & Debt 2 & Inv1 & Inv2 & Coupon 1 & Lev $_{\mathbf{1}}$ \\
\cline { 2 - 11 } & 219.464 & 238.614 & 73.664 & 6.318 & 140.302 & 76.483 & 50 & 36.495 & 12 & 0.46 \\
$\boldsymbol{\sigma}=\mathbf{0 . 2 0}$ & 199.632 & 234.084 & 57.494 & 8.306 & 97.100 & 75.473 & 50 & 33.640 & 9 & 0.34 \\
$\boldsymbol{\sigma}=\mathbf{0 . 3 0}$ & 191.659 & 230.086 & 51.183 & 9.896 & 86.003 & 70.129 & 50 & 29.715 & 9 & 0.32 \\
$\boldsymbol{\sigma}=\mathbf{0 . 4 0}$ & 188.034 & 218.655 & 53.130 & 12.985 & 108.592 & 56.192 & 50 & 20.766 & 15 & 0.42
\end{tabular}

Notes: The model with no equity or debt constraints is used. Base case parameters are: $P=10$ (out-of-money) or $P=30$ (in-themoney), $\mathrm{C}=0$, risk-free rate $r=0.06$, volatility $\sigma=0.2$, competitive erosion $\delta=0.06$, investment cost $I_{1}=50, I_{2}=50, b=0.5$, tax rate $\tau=0.35$ and $\mathrm{T}_{1}=0, \mathrm{~T}_{2}=5$ (time of second option relative to the first), $\mathrm{T}_{\mathrm{F}}=20$ and debt maturity $\mathrm{T}_{\mathrm{D} 1}=20$ and $\mathrm{T}_{\mathrm{D} 2}=15$ assuming zero principal. Initial $(t=0)$ expansion factor at $T_{1}$ is $e_{1}=1$ and subsequent expansion factor at $T_{2}$ is $e_{2}=0$ (no expansiongrowth). An optimal coupon is chosen based on $\mathrm{n}_{\mathrm{c}}=20$ discretization points for each price level with maximum coupon level points being equal to the price levels $\left(c_{\max }=40\right.$ ). In all tables $N_{d e c}=1$ (yearly decisions) with $\mathrm{N}_{\Delta \mathrm{t}}=24$ steps per year. Lev $\mathrm{v}_{1}$ exhibits oscillations inherent in a numerical lattice based approach and is reported to see the general trend. 
Table 2. Long-term debt with debt interactions: Sensitivity with respect to the level of competitive erosion $\delta$, the expansion factor parameter $e_{2}$ and the investment cost $I_{2}$.

Panel A. Sensitivity with respect to $\delta$.

\begin{tabular}{lcccccccccc} 
& Firm & VU & TB & BC & Debt 1 & Debt 2 & Inv1 & Inv2 & Coupon $_{\mathbf{1}}$ & Lev $_{\mathbf{1}}$ \\
\cline { 2 - 10 } $\boldsymbol{\delta}=\mathbf{0}$ & 83.887 & 130.019 & 40.063 & 4.291 & 59.372 & 59.385 & 50 & 31.904 & 5.5 & 0.36 \\
$\boldsymbol{\delta}=\mathbf{0 . 0 2}$ & 51.014 & 104.858 & 29.350 & 3.340 & 41.694 & 45.502 & 50 & 29.853 & 4 & 0.32 \\
$\boldsymbol{\delta}=\mathbf{0 . 0 4}$ & 26.283 & 82.471 & 21.395 & 2.548 & 32.923 & 30.754 & 50 & 25.036 & 3.5 & 0.32 \\
$\boldsymbol{\delta}=\mathbf{0 . 0 6}$ & 8.122 & 64.171 & 14.948 & 1.743 & 24.712 & 19.738 & 50 & 19.254 & 3 & 0.32
\end{tabular}

Panel B. Sensitivity with respect to $e_{2}$.

\begin{tabular}{|c|c|c|c|c|c|c|c|c|c|c|}
\hline & Firm & Vu & TB & $B C$ & ebt 1 & ebt 2 & Inv1 & Inv2 & Coupon $_{1}$ & $\operatorname{Lev}_{1}$ \\
\hline- & 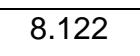 & .171 & .948 & 3 & 2 & .738 & 50 & 9.254 & 3 & .32 \\
\hline$e_{2}=0.5$ & 40.408 & 2 & 5.004 & 9 & 45 & 72 & 50 & 30.829 & 3 & .26 \\
\hline$e_{2}=1$ & 7 & 125.321 & 36.057 & 5.010 & 53.678 & 54.352 & 50 & 32.342 & 5 & 0.34 \\
\hline$e_{2}=1.5$ & 108.287 & 151.677 & 46.921 & 6.783 & 75.804 & 65.039 & 50 & 33.529 & 7 & 0.40 \\
\hline $2=2$ & 142.470 & 178.187 & 57.178 & 8.417 & 93.389 & 78.394 & 50 & 34.478 & 8.5 & 0.41 \\
\hline
\end{tabular}

Panel C. Sensitivity with respect to $I_{2}$.

\begin{tabular}{lcccccccccc} 
& Firm & VU & TB & BC & Debt 1 & Debt 2 & Inv1 & Inv2 & Coupon $_{\mathbf{1}}$ & Lev $_{\mathbf{1}}$ \\
\cline { 2 - 11 } $\mathbf{I n v}_{\mathbf{2}}=\mathbf{0}$ & 47.769 & 79.650 & 22.858 & 4.739 & 51.612 & 18.437 & 50 & 0 & 5 & 0.53 \\
$\mathbf{I n v}_{\mathbf{2}}=\mathbf{1 0}$ & 38.920 & 79.448 & 19.601 & 2.942 & 33.436 & 25.509 & 50 & 7.186 & 3 & 0.35 \\
$\mathbf{I n v}_{\mathbf{2}}=\mathbf{2 0}$ & 30.384 & 77.125 & 18.886 & 2.674 & 31.748 & 24.885 & 50 & 12.952 & 3 & 0.34 \\
$\mathbf{I n v}_{\mathbf{2}}=\mathbf{3 0}$ & 22.106 & 78.028 & 16.430 & 2.168 & 17.018 & 32.094 & 50 & 20.184 & 1.5 & 0.18 \\
$\mathbf{I n v}_{\mathbf{2}}=\mathbf{4 0}$ & 14.590 & 72.407 & 15.655 & 1.991 & 19.786 & 26.934 & 50 & 21.481 & 2 & 0.23 \\
$\mathbf{I n v}_{\mathbf{2}}=\mathbf{5 0}$ & 8.122 & 64.171 & 14.948 & 1.743 & 24.712 & 19.738 & 50 & 19.254 & 3 & 0.32
\end{tabular}

Notes: The model with no equity or debt constraints is used. Base case parameters are: $P=10, \mathrm{C}=0$, risk-free rate $r=0.06$, volatility $\sigma=0.2$, competitive erosion $\delta=0.06$, investment cost $I_{1}=50, I_{2}=50, b=0.5$, tax rate $\tau=0.35$ and $\mathrm{T}_{1}=0$, $\mathrm{T}_{2}=5$ (time of second option relative to the first), $\mathrm{T}_{\mathrm{F}}=20$ and debt maturity $\mathrm{T}_{\mathrm{D} 1}=20$ and $\mathrm{T}_{\mathrm{D} 2}=15$ assuming zero principal. Except in case $\mathrm{B}$ the initial $(t=0)$ expansion factor at $T_{1}$ is $e_{1}=1$ and subsequent expansion factor at $T_{2}$ is $e_{2}=0$ (no expansion-growth). An optimal coupon is chosen based on $\mathrm{n}_{\mathrm{c}}=20$ discretization points for each price level with maximum coupon level points being equal to the

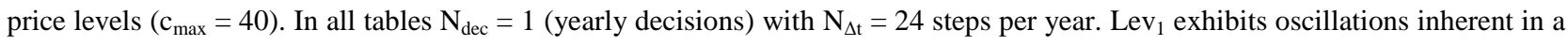
numerical lattice based approach and is reported to see the general trend. 


\section{Table 3. Short term debt with no constraints: Sensitivity to volatility}

Low revenue ( $\mathrm{P}=10)$ (Out-of-the-money case)

\begin{tabular}{|c|c|c|c|c|c|c|c|c|c|c|}
\hline & Firm & Vu & TB & BC & Debt 1 & Debt 2 & Inv1 & Inv2 & Coupon $_{1}$ & $\operatorname{Lev}_{1}$ \\
\hline .10 & 42.776 & 79.275 & 48.971 & 2.497 & 82.289 & 60.126 & 50 & 32.973 & 16.5 & 0.65 \\
\hline$\sigma=0.20$ & 34.600 & 74.358 & 39.691 & 5.624 & 71.392 & 47.635 & 50 & 23.826 & 16 & 0.66 \\
\hline$\sigma=0.30$ & 31.324 & 71.545 & 34.110 & 7.928 & 69.885 & 35.501 & 50 & 16.402 & 18 & 0.72 \\
\hline$\sigma=0.40$ & 31.170 & 70.621 & 31.914 & 7.883 & 66.008 & 33.057 & 50 & 13.481 & 18 & 0.70 \\
\hline
\end{tabular}

High revenue ( $\mathrm{P}=30)$ (In-the-money case)

\begin{tabular}{ccccccccccc} 
& Firm & VU & TB & BC & Debt 1 & Debt 2 & Inv1 & Inv2 & Coupon $_{\mathbf{1}}$ & Lev $_{\mathbf{1}}$ \\
\cline { 2 - 11 } & & & & & & & & & & \\
$\boldsymbol{\sigma}=\mathbf{0 . 1 0}$ & 338.994 & 239.866 & 186.987 & 1.516 & 357.238 & 178.526 & 50 & 36.343 & 69.50 & 0.84 \\
$\boldsymbol{\sigma}=\mathbf{0 . 2 0}$ & 308.403 & 238.949 & 161.221 & 9.284 & 303.839 & 166.076 & 50 & 32.482 & 62.00 & 0.78 \\
$\boldsymbol{\sigma}=\mathbf{0 . 3 0}$ & 281.986 & 235.359 & 138.317 & 15.097 & 273.108 & 137.182 & 50 & 26.594 & 60.50 & 0.76 \\
$\boldsymbol{\sigma}=\mathbf{0 . 4 0}$ & 262.135 & 232.054 & 120.999 & 18.964 & 241.916 & 122.760 & 50 & 21.954 & 57.50 & 0.72
\end{tabular}

Notes: The model with no equity or debt constraints is used. Base case parameters are: $P=10$ (out-of-money) or $P=30$ (in-themoney), $\mathrm{C}=0$, risk-free rate $r=0.06$, volatility $\sigma=0.2$, competitive erosion $\delta=0.06$, investment cost $I_{1}=50, I_{2}=50, b=0.5$, tax rate $\tau=0.35$ and $\mathrm{T}_{1}=0, \mathrm{~T}_{2}=5$ (time of second option relative to the first), $\mathrm{T}_{\mathrm{F}}=20$ and debt maturity $\mathrm{T}_{\mathrm{D} 1}=5$ and $\mathrm{T}_{\mathrm{D} 2}=5$ assuming zero principal. Initial $(t=0)$ expansion factor at $T_{1}$ is $e_{1}=1$ and subsequent expansion factor at $T_{2}$ is $e_{2}=0$ (no expansiongrowth). An optimal coupon is chosen based on $\mathrm{n}_{\mathrm{c}}=20$ discretization points for each price level with maximum coupon level points being equal to the price levels $\left(c_{\max }=40\right)$. In all tables $\mathrm{N}_{\mathrm{dec}}=1$ (yearly decisions) with $\mathrm{N}_{\Delta \mathrm{t}}=24$ steps per year. Lev $\mathrm{e}_{1}$ exhibits oscillations inherent in a numerical lattice based approach and is reported to see the general trend. 
Table 4. Summary of main model predictions about firm value and leverage

\begin{tabular}{|c|c|c|c|c|c|c|c|c|c|}
\hline & & \multicolumn{4}{|c|}{ Long-term debt } & \multicolumn{4}{|c|}{ Short-term debt } \\
\hline Variable & & Firm & Coupon $_{1}$ & Debt $_{1}$ & $\operatorname{Lev}_{1}$ & Firm & Coupon $_{1}$ & Debt $_{1}$ & $\operatorname{Lev}_{1}$ \\
\hline \multirow[t]{2}{*}{ Volatility $(\sigma)$} & $\begin{array}{l}\text { Out-of- } \\
\text { money }\end{array}$ & $U$ & + & + & + & - & U or + & - & + \\
\hline & $\begin{array}{l}\text { In-the- } \\
\text { money }\end{array}$ & - & $U$ & $U$ & $U$ & - & - & - & - \\
\hline $\begin{array}{l}\text { Competitive } \\
\text { erosion ( } \delta \text { ) }\end{array}$ & & - & - & - & - & - & - & - & - \\
\hline $\begin{array}{l}\text { Growth } \\
\text { option } \\
\text { expansion } \\
\left(\mathrm{e}_{2}\right)\end{array}$ & & + & + & + & $U$ & + & + & + & - \\
\hline $\begin{array}{l}\text { Growth } \\
\text { option } \\
\text { investment } \\
\text { cost }\left(\mathrm{I}_{2}\right)\end{array}$ & & - & $U$ & $U$ & $U$ & - & - & - & - \\
\hline
\end{tabular}


Table 5. Equity non-negative net worth constraints: Sensitivity to volatility

Low revenue ( $\mathrm{P}=10$ ) (Out-of-the-money case)

\begin{tabular}{llccccccccc} 
& Firm & VU & TB & BC & Debt 1 & Debt 2 & Inv1 & Inv2 & Coupon $_{\mathbf{1}}$ & Lev $_{\mathbf{1}}$ \\
\cline { 2 - 11 } $\boldsymbol{\sigma}=\mathbf{0 . 1 0}$ & 31.037 & 79.813 & 37.319 & 1.766 & 41.641 & 66.751 & 50 & 34.328 & 8 & 0.36 \\
$\boldsymbol{\sigma}=\mathbf{0 . 2 0}$ & 26.521 & 75.918 & 31.386 & 4.739 & 43.397 & 51.017 & 50 & 26.044 & 9 & 0.42 \\
$\boldsymbol{\sigma}=\mathbf{0 . 3 0}$ & 25.687 & 73.651 & 28.337 & 3.745 & 41.104 & 43.604 & 50 & 22.556 & 9 & 0.42 \\
$\boldsymbol{\sigma}=\mathbf{0 . 4 0}$ & 24.783 & 70.621 & 25.231 & 5.394 & 41.002 & 36.481 & 50 & 15.675 & 10 & 0.45
\end{tabular}

High revenue ( $\mathrm{P}=30$ ) (In-the-money case)

\begin{tabular}{|c|c|c|c|c|c|c|c|c|c|c|}
\hline & Firm & Vu & TB & $\mathrm{BC}$ & Debt 1 & Debt 2 & Inv1 & Inv2 & Coupon $_{1}$ & $\operatorname{Lev}_{1}$ \\
\hline .10 & 262.944 & 239.867 & 111.901 & 3.165 & 117.089 & 205.792 & 50 & 35.659 & 22.5 & 0.34 \\
\hline .20 & 246.437 & 239.845 & 97.930 & 7.525 & 108.555 & 178.769 & 50 & 33.813 & 21 & 0.33 \\
\hline .30 & 238.636 & 238.742 & 90.632 & 10.115 & 119.431 & 149.634 & 50 & 30.624 & 24 & 0.37 \\
\hline$=0.4$ & 227.516 & 236.392 & 81.142 & 12.759 & 107.942 & 136.652 & 50 & 27.259 & 22.5 & 0.35 \\
\hline
\end{tabular}

Notes: The model with equity constraints (debt unconstrained) is used. Base case parameters are: $P=10$ (out-of-money) or $P=30$ (in-the-money), $\mathrm{C}=0$, risk-free rate $r=0.06$, volatility $\sigma=0.2$, competitive erosion $\delta=0.06$, investment cost $I_{1}=50, I_{2}=50, b=$ 0.5 , tax rate $\tau=0.35$ and $\mathrm{T}_{1}=0, \mathrm{~T}_{2}=5$ (time of second option relative to the first), $\mathrm{T}_{\mathrm{F}}=20$ and debt maturity $\mathrm{T}_{\mathrm{D} 1}=5$ and $\mathrm{T}_{\mathrm{D} 2}=5$ assuming zero principal. Initial $(t=0)$ expansion factor at $T_{1}$ is $e_{1}=1$ and subsequent expansion factor at $T_{2}$ is $e_{2}=0$ (no expansiongrowth). An optimal coupon is chosen based on $\mathrm{n}_{\mathrm{c}}=20$ discretization points for each price level with maximum coupon level points being equal to the price levels $\left(c_{\max }=40\right.$ ). In all tables $N_{\text {dec }}=1$ (yearly decisions) with $N_{\Delta t}=24$ steps per year Lev $v_{1}$ exhibits oscillations inherent in a numerical lattice based approach and is reported to see the general trend. 
Table 6. Debt financing constraints: Sensitivity to volatility

Low revenue $(\mathrm{P}=10)$ (Out-of-the-money case)

\begin{tabular}{ccccccccccc} 
& Firm & VU & TB & BC & Debt 1 & Debt 2 & Inv1 & Inv2 & Coupon $_{\mathbf{1}}$ & Lev $_{\mathbf{1}}$ \\
\cline { 2 - 12 } & 16.445 & 78.310 & 23.245 & 0.055 & 38.588 & 27.882 & 50 & 35.055 & 7.5 & 0.38 \\
$\boldsymbol{\sigma}=\mathbf{0 . 1 0}$ & 16.565 & 72.407 & 21.097 & 0.540 & 36.517 & 24.299 & 50 & 26.400 & 7.5 & 0.39 \\
$\boldsymbol{\sigma}=\mathbf{0 . 2 0}$ & 18.571 & 71.545 & 20.081 & 1.009 & 34.908 & 23.476 & 50 & 22.046 & 7.5 & 0.39 \\
$\boldsymbol{\sigma}=\mathbf{0 . 4 0}$ & 20.681 & 70.621 & 19.077 & 1.247 & 33.175 & 22.577 & 50 & 17.770 & 7.5 & 0.38
\end{tabular}

High revenue ( $\mathrm{P}=30)$ (In-the-money case)

\begin{tabular}{ccccccccccc} 
& Firm & VU & TB & BC & Debt 1 & Debt 2 & Inv1 & Inv2 & Coupon $_{\mathbf{1}}$ & Lev $_{\mathbf{1}}$ \\
\cline { 2 - 11 } $\boldsymbol{\sigma}=\mathbf{0 . 1 0}$ & 223.994 & 239.867 & 71.169 & 0.000 & 116.807 & 86.532 & 50 & 37.041 & 22.5 & 0.38 \\
$\boldsymbol{\sigma}=\mathbf{0 . 2 0}$ & 223.946 & 239.779 & 71.110 & 0.024 & 116.736 & 86.461 & 50 & 36.919 & 22.5 & 0.38 \\
$\boldsymbol{\sigma}=\mathbf{0 . 3 0}$ & 222.648 & 238.024 & 69.682 & 0.628 & 114.875 & 84.844 & 50 & 34.430 & 22.5 & 0.37 \\
$\boldsymbol{\sigma}=\mathbf{0 . 4 0}$ & 220.579 & 236.392 & 66.866 & 2.025 & 111.162 & 81.910 & 50 & 30.654 & 22.5 & 0.37
\end{tabular}

Notes: The model with debt constraints (without equity constraints) is used. Base case parameters are: $P=10$ (out-of-money) or $P=$ 30 (in-the-money), $\mathrm{C}=0$, risk-free rate $r=0.06$, volatility $\sigma=0.2$, competitive erosion $\delta=0.06$, investment cost $I_{1}=50, I_{2}=50, b$ $=0.5$, tax rate $\tau=0.35$ and $\mathrm{T}_{1}=0, \mathrm{~T}_{2}=5$ (time of second option relative to the first), $\mathrm{T}_{\mathrm{F}}=20$ and debt maturity $\mathrm{T}_{\mathrm{D} 1}=5$ and $\mathrm{T}_{\mathrm{D} 2}=$ 5 assuming zero principal. Initial $(t=0)$ expansion factor at $T_{1}$ is $e_{1}=1$ and subsequent expansion factor at $T_{2}$ is $e_{2}=0$ (no expansiongrowth). An optimal coupon is chosen based on $n_{c}=20$ discretization points for each price level with maximum coupon level points being equal to the price levels $\left(c_{\max }=15\right)$ implying that coupons cannot exceed $75 \%$ of revenue $(P)$ level at the time of the financing decision. In all tables $\mathrm{N}_{\mathrm{dec}}=1$ (yearly decisions) with $\mathrm{N}_{\Delta \mathrm{t}}=24$ steps per year. $\mathrm{Lev}_{1}$ exhibits oscillations inherent in a numerical lattice based approach and is reported to see the general trend. 


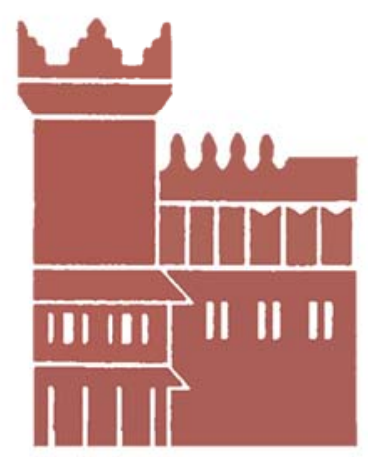

Alma Mater Studiorum - Università di Bologna DEPARTMENT OF ECONOMICS

Strada Maggiore 45

40125 Bologna - Italy

Tel. +39051 2092604

Fax +390512092664

http://www.dse.unibo.it 